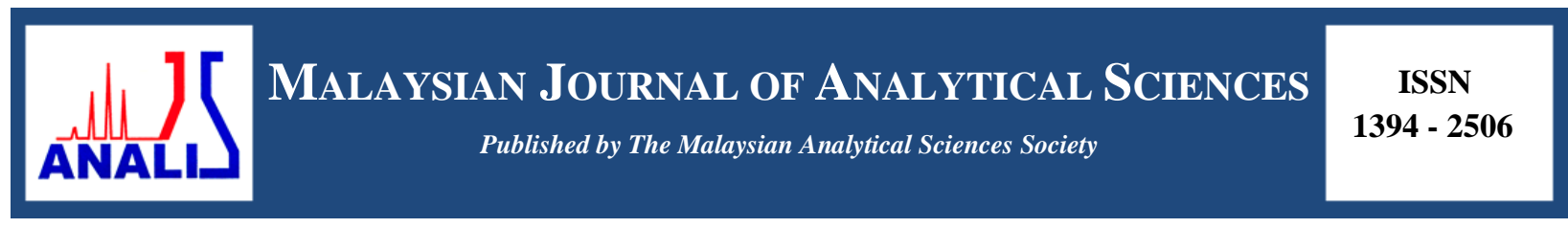

\title{
MITIGATION OF TOXIC Alexandrium tamiyavanichii USING CHITOSAN-SILICA COMPOSITE
}

\author{
(Mitigasi Alexandrium tamiyavanichii Bertoksik Menggunakan Komposit Kitosan-Silika) \\ Anwar Iqbal ${ }^{1 *}$, Najwa Ahmad ${ }^{2}$, Normawaty Mohammad Noor ${ }^{2}$, Lee D. Wilson ${ }^{3}$, Nur Hanisah Ibrahim ${ }^{1}$ \\ ${ }^{1}$ School of Chemical Sciences, \\ Universiti Sains Malaysia, 11800 USM Penang, Malaysia \\ ${ }^{2}$ Department of Marine Science, Kulliyyah of Science, \\ International Islamic University Malaysia, Jalan Sultan Ahmad Shah, Bandar Indera Mahkota, 25200 Kuantan, Pahang, \\ Malaysia \\ ${ }^{3}$ Department of Chemistry, 110 Science Place, Room 156 Thorvaldson Building, \\ University of Saskatchewan, Saskatoon, S7N 5 C9 Canada \\ *Corresponding author: anwariqbal@usm.my
}

Received: 24 January 2018; Accepted: 13 September 2018

\begin{abstract}
The harmful algal bloom (HABs) phenomena affects human health, ecosystems, fishing, and tourism industries. In a single occasion, the loss due to HABs can reach thousands of Ringgit Malaysia. In this study, a chitosan-silica composite (RHA-CHi) was synthesized via sol-gel technique for the mitigation of Alexandrium tamiyavanichii, a toxic HAB species isolated from Malaysian waters. Rice husk ash silica was used as the silica precursor in the composite synthesis. The FT-IR spectroscopy suggests that the chitosan was covalently bonded with the surface silanol groups. Light microscope analysis showed that the algal cells were stuck on the surface of the composite and underwent lysis. The incorporation of chitosan decreased the surface negative charge of the silica, hence, increasing the electrostatic attraction between the cells and RHA-Chi. The removal efficiency of A. tamiyavanichii was $75 \%$ using $0.1 \mathrm{mg} / \mathrm{mL}$ of RHA-Chi in 2 hours, increasing to $85 \%$ after 24 hours. Reduced removal efficiency $(16 \%)$ was observed using silica alone. The findings show that the chitosan-silica composite has high potential to be used in the mitigation of A. tamiyavanichii.
\end{abstract}

Keywords: toxic algae, flocculate, silica, chitosan, rice husk

\begin{abstract}
Abstrak
Fenomena ledakan alga-bahaya mengancam kesihatan manusia, industri perikanan dan pelancongan. Dalam satu kejadian, kerugian boleh mencecah ribuan Ringgit Malaysia. Dalam kajian ini, komposit kitosan-silika (RHA-CHi) telah disintesis melalui kaedah sol-gel untuk mitigasi Alexandrium tamiyavanichii, spesis bertoksik HAB yang dipencilkan dari perairan Malaysia. Abu sekam padi telah digunakan sebagai pelopor silika dalam sintesis komposit. Spektroskopi FT-IR menunjukkan kitosan terikat secara kovalen dengan kumpulan silanol permukaan. Analisis mikroskopi cahaya menunjukkan sel alga melekat pada permukaan komposit dan mengalami lisis. Penggabungan kitosan telah mengurangkan cas negatif permukaan silika lalu meningkatkan tarikan elektrostatik antara sel dan RHA-Chi. Kecekapan penyingkiran A. tamiyavanichii dalam masa $2 \mathrm{jam}$ apabila $0.1 \mathrm{mg} / \mathrm{ml}$ RHA-Chi digunakan adalah 75\% dan meningkat ke 85\% selepas 24 jam manakala pengurangan kecekapan penyingkiran (16\%) diperhatikan bagi silika sahaja. Penemuan ini menunjukan komposit kitosan-silika mempunyai potensi yang tinggi untuk digunakan dalam mitigasi ledakan alga-bahaya terutamanya $A$. tamiyavanichii.
\end{abstract}

Kata kunci: alga beracun, mengumpal, silika, kitosan, sekam padi 


\section{Introduction}

Climate change has an adverse effect on aquatic environment. Variation in water condition may cause transformation in phytoplankton community structure and composition, including a greater prevalence and geographical spread of harmful algal blooms (HABs) [1]. Under the right conditions (salinity, temperature, and nutrients) some algae tend to grow in a higher number to form a bloom. Most algal blooms are not harmful, but they do cause serious problems such as discoloration of water, produce a smelly odor or bad water taste. Besides, the algal bloom depletes the concentration of oxygen available in the water through respiration. As a result, many organisms particularly caged fishes (relevant to fish farms) will die. The problem does not stop there. At the end of the blooming season and as the algae begins to die, more oxygen will be used by the microbes to decompose the algae cells creating an oxygen-deprived zone known as hypoxic dead zones. In this zone, neither fish nor plants can survive.

Alexandrium tamiyavanichii is a toxic dinoflagellate that causes paralytic shellfish poisoning (PSP). The first case of PSP by this species was recorded in Sebatu, Malacca whereby mussels were banned from being consumed. This caused an economic problem for the breeders [2]. The second case was in Kuantan Port, Pahang where ten people were hospitalized [3]. The occurrence of this species and other HAB species indicate that HABs are a serious problem that require further attention, especially as it affects human and the ecosystem, as evidenced by the negative impact to fisheries and tourism industries.

Mitigation is a term used to describe the actions taken to deal with an existing or ongoing bloom by taking necessary precautions to reduce the negative impact of the bloom. To date, many physical [4-6], chemical [7,8] and biological approaches have been proposed for the mitigation of HABs [9-10].

Although these approaches may be effective, some methods have certain drawbacks. The chemical approach is not selective towards certain $\mathrm{HAB}$ species and may affect other parts of the aquatic ecosystem. The chemical compounds can eliminate or negatively impact organisms that are required to balance the aquatic ecosystem [11]. The biological approach is considered safe and often species selective [12], but its efficiency depends on many biotic and abiotic factors. In comparison to chemical and biological approaches, physical methods often pose fewer threats to aquatic environment.

The objective of this research is to mitigate toxin producing HAB species, A. tamivanichii using a physical approach based on the properties of a chitosan-silica composite. The chitosan-silica composite was prepared using a one-pot synthesis via a sol-gel method. This research will contribute towards new knowledge for mitigating HAB species and help to minimize the impact of HABs on human health, particularly in Malaysia.

\section{Preparation of rice husk ash}

\section{Materials and Methods}

The preparation of rice husk ash (RHA) was carried out according to the reported method by Adam et al. [13]. Dirt and other water-soluble impurities were removed from the rice husk $(\mathrm{RH})$ by washing it with copious amount of water and dried in the oven at $70{ }^{\circ} \mathrm{C}$ overnight. The clean and dried $\mathrm{RH}$ was stirred for 24 hours in $1.0 \mathrm{M} \mathrm{HNO}_{3}$ to remove metallic impurities. The acid treated RH was then filtered using 8 " sieve with mesh size $125 \mathrm{~mm}-20 \mu \mathrm{m}$ and washed with distilled water until the $\mathrm{pH}$ of the filtrate became constant. The acid treated $\mathrm{RH}$ was dried in the oven at $70{ }^{\circ} \mathrm{C}$ overnight. The $\mathrm{RH}$ was then pyrolyzed in a furnace at $600^{\circ} \mathrm{C}$ for 6 hours to produce RHA.

\section{Preparation of silica from RHA}

Sodium silicate solution was prepared by dissolving $3 \mathrm{~g}$ of RHA in $350 \mathrm{~mL}$ of $1.0 \mathrm{M} \mathrm{NaOH}$ for 24 hours. The sodium silicate solution was titrated with $3.5 \mathrm{M} \mathrm{HCl}$ with constant stirring until $\mathrm{pH} 3$. As the solution reached $\mathrm{pH}$ 10 , gel started to form. The gel was aged for 24 hours in the mother liquor in a closed plastic container. The gel was separated using centrifugation (HETTICH ${ }^{\circledR}$ Rotina 38 ) at $7000 \mathrm{rpm}$ for 9 minutes. The recovered gel was dried at 70 ${ }^{\circ} \mathrm{C}$ for 24 hours. The dried xerogel was weighed before grinding with a mortar and pestle into a fine powder. The resulting white powder ( $\mathrm{RHA}-\mathrm{SiO}_{2}$ ) was stored in a glass bottle for use in this study. 


\section{Synthesis of chitosan-silica composite}

The composite was prepared similarly to the preparation method of sodium silicate with some modification. Chitosan (1 g) (Sigma-Aldrich, 75-85\% deacetylated) was dissolved in $3.5 \mathrm{M} \mathrm{HCl}$. The sodium silicate solution was titrated with the aqueous chitosan solution until $\mathrm{pH} 3$. The yellow colored gel was aged for 24 hours before separation by centrifugation at $7000 \mathrm{rpm}$. The gel was dried at $70{ }^{\circ} \mathrm{C}$ for 24 hours. The yellow colored xerogel was ground to a fine powder and labeled as RHA-Chi.

\section{Characterization}

The FTIR spectra of the materials were obtained using a Perkin Elmer System 2000 spectrophotometer. Approximately 0.1 to $1.0 \mathrm{wt} . \%$ sample was mixed with $200-250 \mathrm{mg}$ of fine potassium bromide powder by grinding in a mortar and pestle. The samples were prepared in pellet form and then analyzed in transmission mode over a wavelength range $\left(400-4000 \mathrm{~cm}^{-1}\right)$ at a resolution of $4 \mathrm{~cm}^{-1}$.

\section{Culture of Alexandrium tamiyavanichii}

The subculture of A. tamiyavanichii was prepared from the stock culture ( $\mathrm{f} / 2$ medium) obtained from the Phycology Laboratory, Kulliyyah of Science, International Islamic University Malaysia. The culture was maintained in $\mathrm{f} / 2$ medium, at 12:12 light and dark cycle and temperature of $\pm 27^{\circ} \mathrm{C}$.

\section{Algal mitigation and flocculation}

For the algal mitigation and flocculation tests, three concentrations $(0.01 \mathrm{mg} / \mathrm{mL}, 0.1 \mathrm{mg} / \mathrm{mL}$ and $1.0 \mathrm{mg} / \mathrm{mL})$ of RHA- $\mathrm{SiO}_{2}$ and RHA-Chi were used against $15 \mathrm{~mL}$ of $A$. tamiyavanichii culture containing \pm 1000 cells $/ \mathrm{mL}$. The

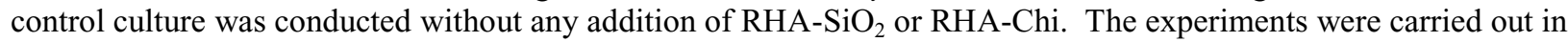
triplicate in $60 \times 10 \mathrm{~mm}$ petri dish. After the addition of $\mathrm{RHA}-\mathrm{SiO}_{2}$ or RHA-Chi, the $\mathrm{pH}$ of the medium was measured using a pH meter with a glass electrode. At variable intervals of $0,1,2,6,12$ and 24 hours, after the addition of $\mathrm{RHA}-\mathrm{SiO}_{2}$ or RHA-Chi, $1.0 \mathrm{~mL}$ of sample aliquots were taken using micropipette. The cells were counted in a Sedgewick-Rafter cell after being fixed with Lugol's solution. The effectiveness of this method is determined by the value of Removal Efficiency (RE). Equation (1) was used to calculate the RE of the cells. The accumulated algae flocs were taken using a pipette and observed under a light microscope (Olympus CH30 Light microscope). Pictures were taken using Dino Capture 2.0 at a total magnification of $400 \times$.

$$
(\mathrm{RE})=\frac{1 \text {-Number of live cells in test }}{\text { Number of live cells in control }} \times 100 \%
$$

\section{Characterization of the composite}

\section{Results and Discussion}

The FTIR spectrum of chitosan is shown in Figure 1(a). The stretching vibration of $-\mathrm{OH}$ groups of chitosan show a broad band at $3470 \mathrm{~cm}^{-1}$, that may include contributions of N-H symmetrical stretching vibration of amine [14]. The $-\mathrm{CH}$ symmetric and asymmetric vibrations give rise to the transmission bands at 2919 and $2960 \mathrm{~cm}^{-1}$, respectively. The band at $1598 \mathrm{~cm}^{-1}$ is due to the stretching vibration of amino groups. The weak bands at 1380 and $1421 \mathrm{~cm}^{-1}$ are due to the bending vibration of $-\mathrm{CH}_{2}$ and symmetry deformation of $-\mathrm{CH}_{3}$, respectively [15]. The FTIR band located at $1154 \mathrm{~cm}^{-1}$ is due to the asymmetric vibration of $\mathrm{C}-\mathrm{O}$ in the oxygen bridge resulting from deacetylation of chitosan [16]. The bands within $1080-1025 \mathrm{~cm}^{-1}$ are attributed to the stretching vibration of $\mathrm{C}-\mathrm{O}$ of the ring, $\mathrm{COH}$, $\mathrm{COC}$, and $\mathrm{CH}_{2} \mathrm{OH}$. The wagging of the saccharide structure of chitosan is characterized by the band around 890 $\mathrm{cm}^{-1}[17]$.

The FTIR spectrum of RHA-SiO ${ }_{2}$ is shown in Figure 1(b). The stretching vibration of $\mathrm{SiO}-\mathrm{H}$ bond and adsorbed water (HO-H) on the silica surface yields a broad peak with an envelope-like appearance around $3469 \mathrm{~cm}^{-1}[18]$. The sharp band at $1639 \mathrm{~cm}^{-1}$ is attributed to the bending mode of absorbed water molecules on the silica, while the stretching vibration of Si-O-Si bond reveals a band observed at $1080 \mathrm{~cm}^{-1}[19]$. The band at $968 \mathrm{~cm}^{-1}$ is due to the stretching vibration of the Si-OH bonds [20]. The symmetric stretching and bending modes of the bulk Si-O-Si bond is indicated by the bands at 801 and $467 \mathrm{~cm}^{-1}$, respectively [21]. 


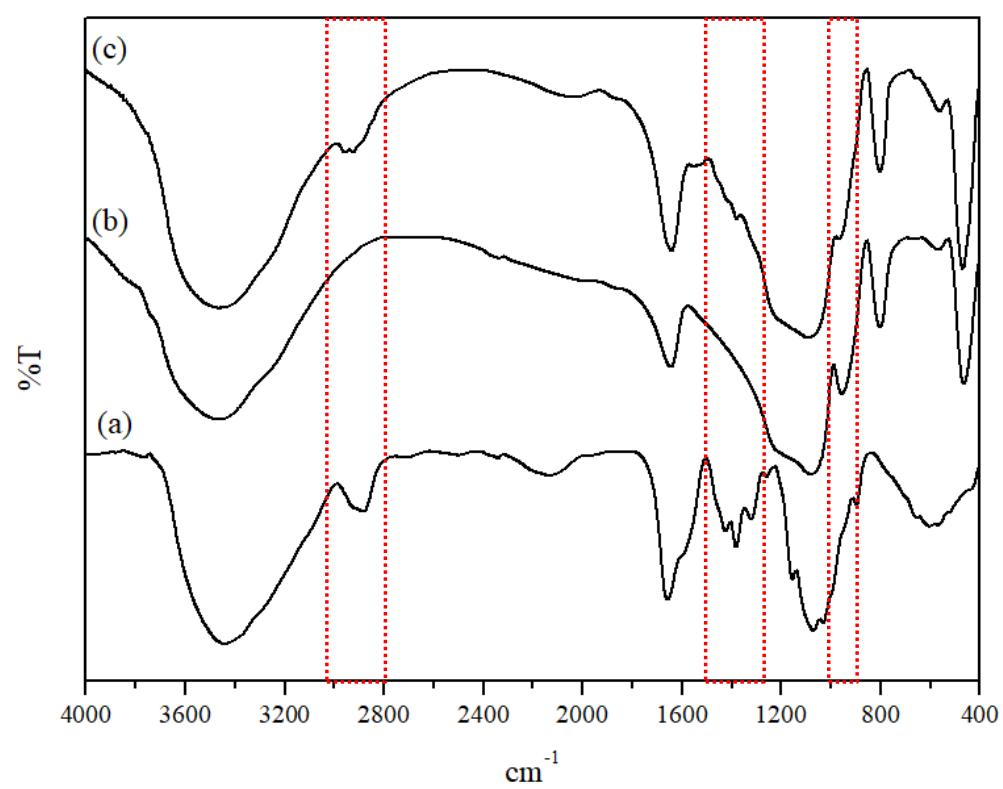

Figure 1. The FTIR spectra of (a) chitosan, (b) RHA-SiO 2 and (c) RHA-Chi

The FTIR spectrum of RHA-Chi is shown in Figure 1(c), where many of the bands related to the functional groups of silica and chitosan are extensively overlapped, and only a few prominent bands are resolved. The prominent bands are indicated using red boxes. The $-\mathrm{CH}$ symmetric and asymmetric vibrations of the chitosan can still be seen $\sim 2900$ and $1300 \mathrm{~cm}^{-1}$. However these bands appears weaker compared to chitosan. Bands related to the stretching vibration of Si-OH, symmetric stretching and bending modes of bulk Si-O-Si bond can be seen at $968 \mathrm{~cm}^{-1}$ and 463 $\mathrm{cm}^{-1}$, respectively. However, the intensity of the stretching vibration of $\mathrm{Si}-\mathrm{OH}$ bond seems to be drastically reduced as compared to RHA- $\mathrm{SiO}_{2}$ which indicates that bond formation occurs between the surface silanol groups of silica with the hydroxyl group of chitosan. The appearances of these bands indicated that chitosan had bonded onto silica forming a new composite.

The interaction between the hydroxyl groups of chitosan with the surface silanol groups of silica may have formed covalent bond via a condensation reaction shown by the reaction scheme in Figure 2 [22-24].

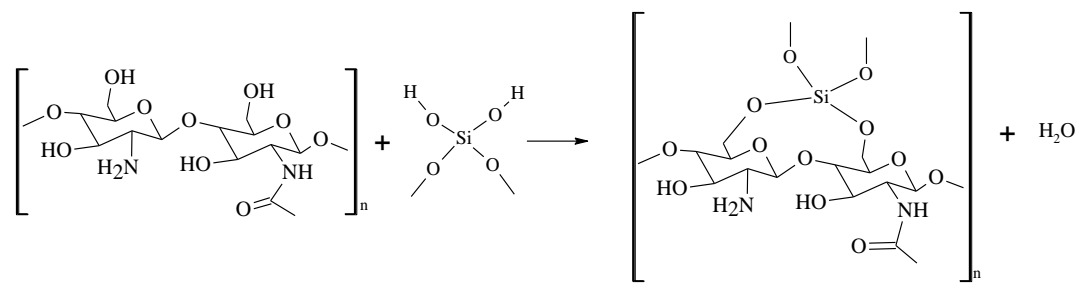

Figure 2. The condensation of the hydroxyl group of chitosan with the surface silanol groups of silica

In acidic condition, the amino groups of chitosan will be protonated, where the $-\mathrm{NH}_{3}{ }^{+}$group has a high affinity for the negatively charged silicate species [25]. The $-\mathrm{NH}_{3}{ }^{+}$group can form a more stable hydrogen bond with the silanol groups as compared to an uncharged $\mathrm{NH}_{2}$ group. The electrostatic interaction between the protonated amino group of chitosan with the negatively charged dissociated hydroxyl silica is shown in Figure 3. 


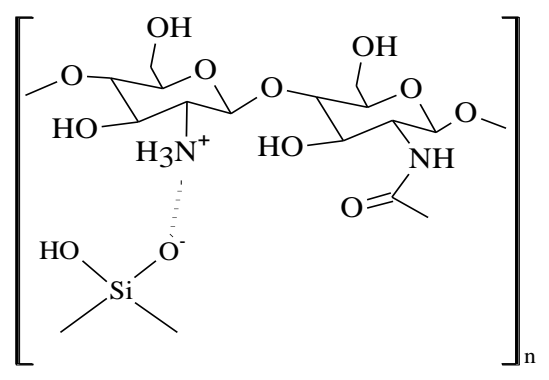

Figure 3. The interaction scheme between the protonated amine of chitosan with the negatively charged dissociated hydroxyl silica

The application of chitosan in seawater are limited due to the high alkalinity and ionic strength of seawater. The high alkalinity and ionic strength of seawater will prevent the polymer chitosan chain from unfolding. This will weaken the netting and the bridging properties of the chitosan [26]. The chitosan-silica linkages is expected to create a net-like structure that is flexible yet rigid. The macromolecular structure is expected to remain unfolded in seawater, resulting in more adsorption sites for the alga cells to be bound to the composite material.

\section{Light microscopy analysis}

The physical appearances of RHA- $\mathrm{SiO}_{2}$ and RHA-Chi under a light microscope at a magnification of 400x are shown in Figures 4(a) and (b), respectively. Based on these optical images, $\mathrm{RHA}-\mathrm{SiO}_{2}$ has the appearance of transparent glass-like particles, while RHA- Chi is opaque and porous. The change in morphology and the physical appearance indicate the formation of a unique composite between chitosan and the silica matrix.
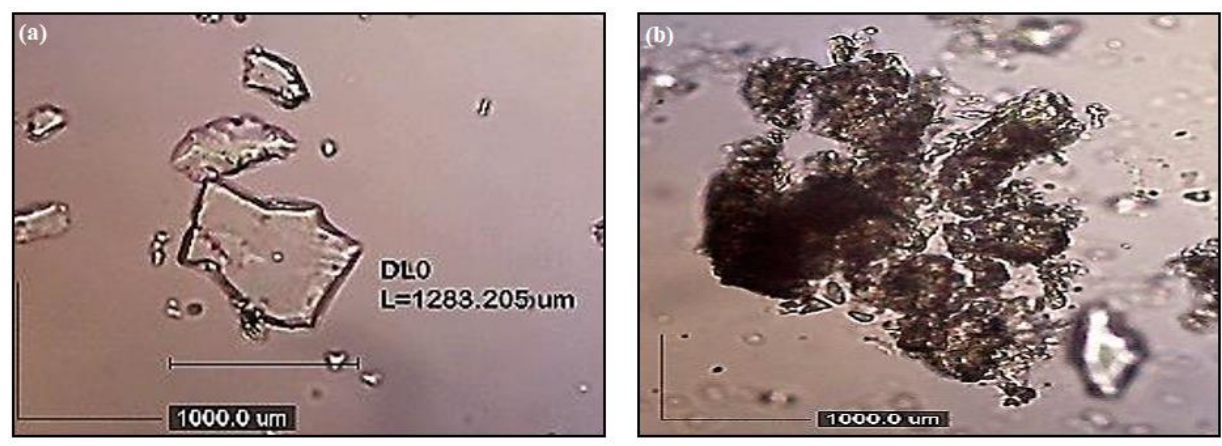

Figure 4. The micrographs of (a) transparent glass-like $\mathrm{RHA}-\mathrm{SiO}_{2}$ and (b) opaque and porous RHA-Chi composite material

\section{Removal efficiency of $A$. tamiyavanichii using $\mathrm{RHA}^{-\mathrm{SiO}_{2}}$}

The HAB cells were observed to be immediately attracted to the $\mathrm{RHA}-\mathrm{SiO}_{2}$ when it was added. The RE values at different concentrations of RHA- $\mathrm{SiO}_{2}$ is shown in Figure 5. The use of a concentration of $0.01 \mathrm{mg} / \mathrm{mL}$ and 0.1 $\mathrm{mg} / \mathrm{mL}$ gave a RE value of $36 \%$ and $64 \%$, respectively, in the first 2 hours. After 24 hours, the RE value dropped to $6 \%$ and $16 \%$, respectively. This effect indicates that the $\mathrm{RHA}^{-\mathrm{SiO}_{2}}$ is only able to temporarily trap the algal cell but did not kill them. The $\mathrm{pH}_{\mathrm{ZPC}}$ of silica is around 2.0. Above the $\mathrm{pH}_{\mathrm{ZPC}}$ value, the surface of the silica will be negatively charge and will repel the negatively charged algal cells. Throughout the experiment, the algal cells were not seen to be fully attached to the material as observed under the light microscope (Figure 6(a)). This finding is similar to that reported by Pan et al. [6], where the addition of unmodified beach sand was ineffective in removal of algal cells from the water column. The RE values were below $10 \%$ after 4 hours, indicating that sand alone did not have any flocculation ability. Instead, may act as a mass provider or ballast to carry flocs formed by modifiers to 
the bottom of the water column [6]. The initial $\mathrm{pH}$ of the medium containing A. tamiyavanichii was $\mathrm{pH} 8.22$ prior to the addition of RHA-SiO ${ }_{2}$, where a decrease to $\mathrm{pH} 8.01$ occurred in the presence of the composite $(0.01 \mathrm{mg} / \mathrm{mL})$ and to $\mathrm{pH} 7.44$ at a higher composite dosage $(0.1 \mathrm{mg} / \mathrm{mL})$. Within 2 hours after the addition of $1.0 \mathrm{mg} / \mathrm{mL}$ of RHA$\mathrm{SiO}_{2}$, the calculated $\mathrm{RE}$ value was $70 \%$. After 24 hours, the RE was at a favorable value of $84 \%$. However, the medium became acidic ( $\mathrm{pH}$ 6.18) at this condition. The mortality of $A$. tamitayavanichii may relate to the acidic $\mathrm{pH}$ conditions and not because of mitigation. Since the $\mathrm{pH}$ of the medium became acidic in the presence of excess RHA- $\mathrm{SiO}_{2}$, the data suggest that it may not be safe to other aquatic environments. Most marine phytoplankton can only adapt to $\mathrm{pH}$ conditions near 7.8 [27]. Statistical analysis revealed that there were significant differences between each concentration tested $(\mathrm{p}<0.05)$.

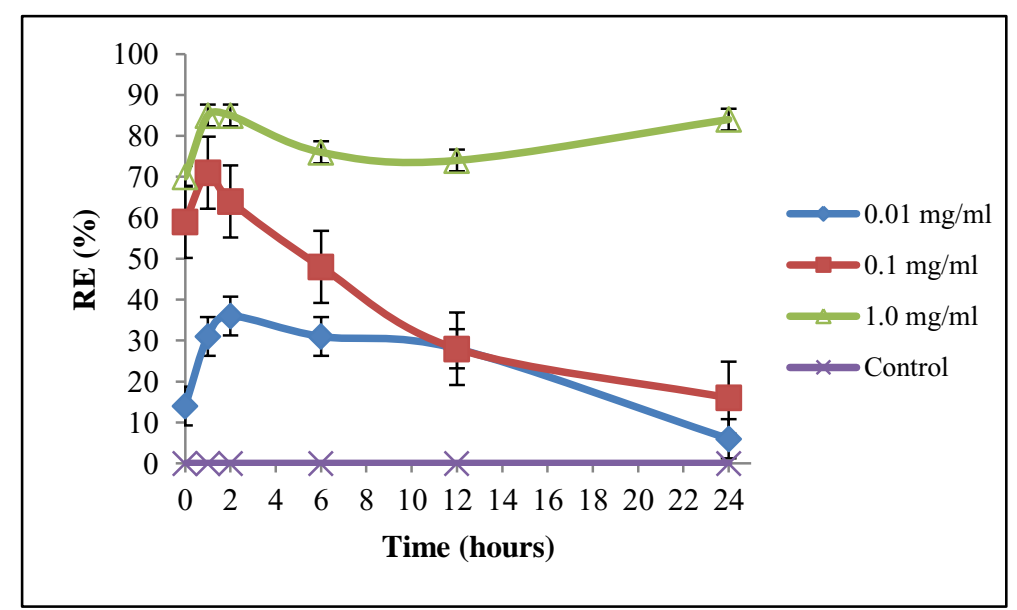

Figure 5. Time dependent Removal Efficiencies (REs) for variable dosage of the $\mathrm{RHA}^{-\mathrm{SiO}_{2}}$ composite material
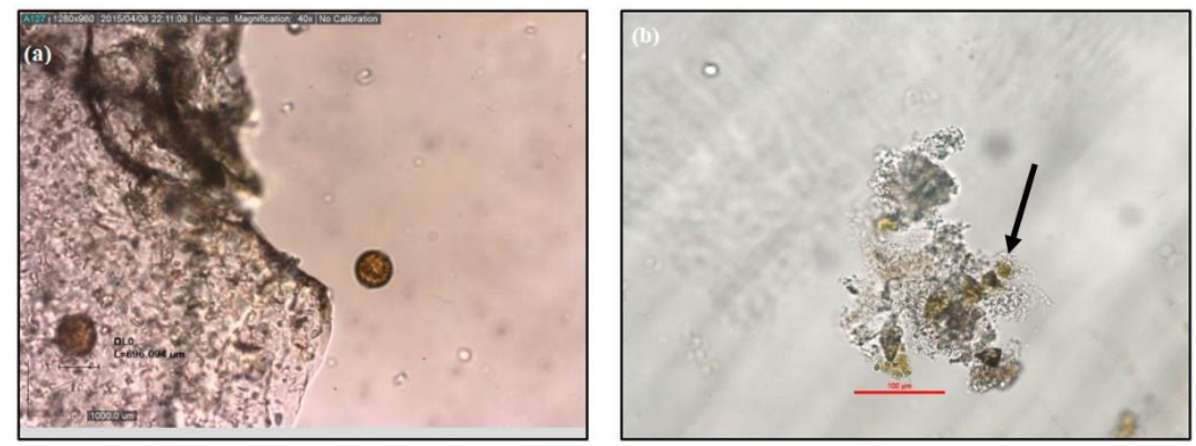

Figure 6. Micrographs showing the attachment of algae cells on (a) $\mathrm{RHA}-\mathrm{SiO}_{2}$ and (b) RHA-Chi

\section{Removal efficiency of $A$. tamiyavanichii using RHA-Chi}

The HAB cells immediately got attracted to the RHA-Chi as well when it was added. The RE values of $A$. tamiyavanichii using RHA-Chi are shown in Figure 7. Similar trends for all three dosages tested on $A$. tamiyavanichii with significant differences between these conditions $(\mathrm{p}<0.05)$ were observed. The RE achieved when $1.0 \mathrm{mg} / \mathrm{mL}$ of RHA-Chi was used after 2 hours was $100 \%$, however, the $\mathrm{pH}$ of the medium dropped to 5.42 . Most of the algal cells were dead after 24 hours but not many were attached to RHA-CHi when viewed under a light microscope (image is not shown).

For the dosages of 0.01 and $0.1 \mathrm{mg} / \mathrm{mL}$, the calculated RE values were $45 \%$ and $75 \%$ after 2 hours, respectively. By comparison, the RE values reached $85 \%$ at 24 hours for $0.1 \mathrm{mg} / \mathrm{mL}$ and $75 \%$ for $0.01 \mathrm{mg} / \mathrm{mL}$. The pH of the culture medium was 7.40 and 7.86 when $0.1 \mathrm{mg} / \mathrm{mL}$ and $0.01 \mathrm{mg} / \mathrm{mL}$ RHA-Chi composite was added. The $\mathrm{pH}$ is at 
an acceptable range and deemed safe to other aquatic animals [27]. As seen in Figure 6(b), the algal cells are attached strongly to the surface of the composite. The interaction between the algal cells and chitosan is proposed to take place through electrostatic interactions between the composite and the algal cells. The incorporation of chitosan may have reduced the surface negative charge of the silica. As a result, the electrostatic attraction between the algal cells and the composite increased. The electrostatic interaction may cause internal osmotic imbalance leading to the lysis of the cell wall $[28,29]$. As a result of cell wall lysis, leakage of intracellular content takes place as indicated by the arrow in Figure 6(b). The leaked intracellular content is still attached to the composite.

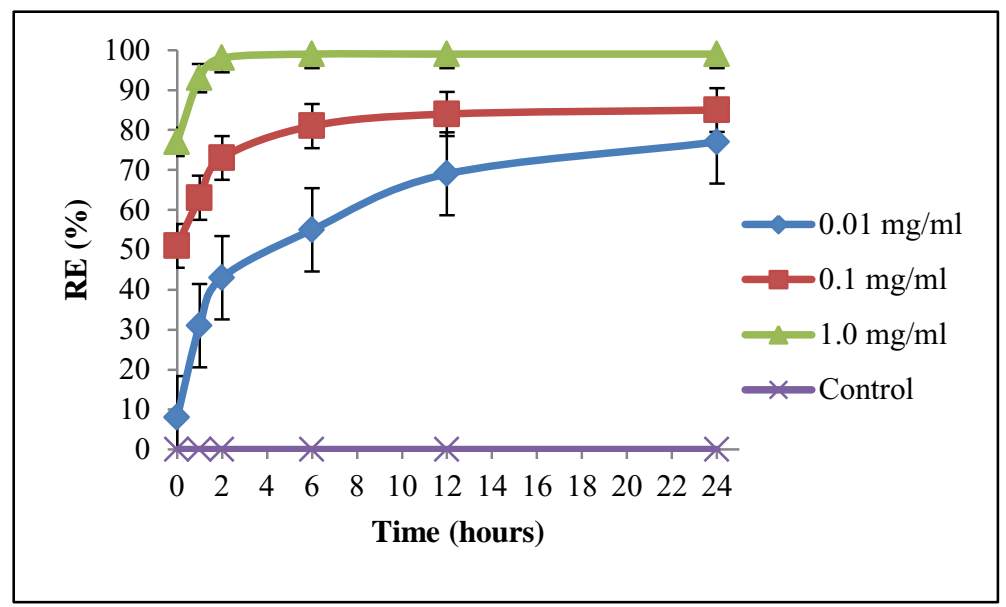

Figure 7. Time dependent Removal Efficiencies (REs) for different concentrations of RHA-Chi

The use of RHA-Chi for the mitigation of HABs offers a few advantages compared to several other current mitigation techniques. Firstly, this hybrid material displayed less environmental issues as both raw materials, i.e. rice husk ash (RHA) and chitosan are biocompatible and biodegradable. By comparison with the study by Pan et al. [6], PAC was used as a critical component in their mitigation of HAB, where this approach raised environmental concerns related to the balance of seawater. Secondly, the use of RHA-Chi is more cost effective since rice husk can be easily acquired free or at a low price from the rice milling industry and chitosan is a low-priced commercially available biomaterial.

\section{Conclusion}

RHA-Chi has been successfully deployed to capture, mitigate and flocculate the algal cells of A. tamiyavanichii as compared with $\mathrm{RHA}-\mathrm{SiO}_{2}$. The optimal concentration of RHA-Chi identified to mitigate A. tamiyavanichii was 0.1 $\mathrm{mg} / \mathrm{mL}$ with an immediate effect of 50\% RE in 2 hours, where the dosage does not cause significant change on the $\mathrm{pH}$ of the algal culture. The algal cells are proposed to be attached to the the composite via electrostatic attraction, whereas silica alone acted as a ballast to carry the formed flocks. RHA-Chi is suitable for application as a material for mitigation of A. tamiyavanichii because of its biocompatibility, biodegradability, and cost-effectiveness. The findings from this research can be used as a platform to further optimize and scale-up the study.

\section{Acknowledgement}

This study was supported by Universiti Sains Malaysia Short Term Grant (304/PKIMIA/6313215), Universiti Sains Malaysia Research University Grant (RUI) (1001/PKIMIA/8011083) and Fundamental Research Grant Scheme (FRGS-13-035-0276), Ministry of Higher Education (MOHE) Malaysia.

\section{References}

1. Wells, M. L., Trainer, V. L., Smayda, T. J., Karlson, B. S. O., Trick, C. G., Kudel, R. M., Ishikawa, A., Bernard, S., Wulfi, A., Anderson, D. M. and Cochlan, W. P. (2015). Harmful algal blooms and climate change: learning from the past and present to forecast the future. Harmful Algae, 49: 68-93. 
2. Usup, G., Leaw, C. P., Asmat, A. and Lim, P. T. (2002). Alexandrium (Dinophyceae) species in Malaysian waters. Harmful Algae, 1: 265-75.

3. Mohammad-Noor, N., Aimimuliani A., Po T. L., Chui P. L., Winnie L. S. L., G. R. Liow, Noraslinda M. B., Nurul A. H., Azlan M. N., Norazizah, K. and Devaraj, M. (2017). First report of paralytic shellfish poisoning (PSP) caused by Alexandrium tamiyavanichii in Kuantan Port, Pahang, East Coast of Malaysia. Phycological Research, 66:37-44.

4. Liu, Y., Cao, X., Yu, Z., Song, X. and Qiu, L. (2016). Controlling harmful algae blooms using aluminummodified clay. Marine Pollution Bulletin, 103: 211-219.

5. Hao, H., Wu, M., Chen, Y., Tang, J. and Wu, Q. (2004). Cavitation mechanism in cyanobacterial growth inhibition by ultrasonic irradiation. Colloids and Surfaces B: Biointerfaces, 33: 151-156.

6. Pan, G., Jin, C. and Anderson, D. M. (2011). Modified local sands for the mitigation of harmful algal blooms. Harmful Algae, 10: 381-387.

7. Laue, P., Bährs, H., Chakrabarti, S. and Christian, S. E. W. (2014). Natural xenobiotics to prevent cyanobacterial and algal growth in freshwater: Contrasting efficacy of tannic acid, gallic acid, and gramine. Chemosphere, 104: 212-220.

8. Fan, J., Ho, L., Hobson, P. and Brookes, J. (2013). Evaluating the effectiveness of copper sulphate, chlorine, potassium permanganate, hydrogen peroxide and ozone on cyanobacterial cell integrity. Water Research, 47: 5153-5164.

9. Ying, Z. T., Yoonja K., Dianna B. and Christopher J. G. (2015). The ability of the red macroalga, Porphyra purpurea (Rhodophyceae) to inhibit the proliferation of seven common harmful microalgae. Journal of Applied Phycology, 27:531-544.

10. Marcoval, M. A., Pan, J., Tang, Y. and Gobler, C. J. (2013). The ability of the branchiopod, Artemia salina, to graze upon harmful algal blooms caused by Alexandrium fundyense, Aureococcus anophagefferens, and Cochlodinium polykrikoides. Estuarine, Coastal Shelf Science, 131: 235-244.

11. Jančula, D. and Maršálek, B. (2011). Critical review of actually available chemical compounds for prevention and management of cyanobacterial blooms. Chemosphere, 85: 1415-1422.

12. Shao, J., Li, R., Lepo, J. E. and Gu, J. D. (2013). Potential for control of harmful cyanobacterial blooms using biologically derived substances: Problems and prospects. Journal of Environmental Management, 125: 149155.

13. Adam, F., H. Osman, and Mohammed, H. K. (2009). The immobilization of 3-(chloropropyl)triethoxysilane onto silica by simple one pot synthesis. Journal of Colloid and Interface Science, 331:143-147.

14. Ramya, R., Sudha, P. N. and Mahalakshmi, J. (2012). Preparation and characterization of chitosan binary blend. International Journal of Scientific and Research Publications, 2(10): 1-9.

15. Mano, J. F., Koniarova, D. and Reis, R. L. (2003). Thermal properties of thermoplastic starch/synthetic polymer blends with potential biomedical applicability. Journal of Materials Science: Materials in Medicine, 14: $127-135$.

16. Xu, Y., Kim, K., Hanna, M. and Nag, D. (2005). Chitosan-starch composite film: Preparation and characterization. Industrial Crops and Products, 21: 185-192.

17. Paluszkiewicz, C., Stodolak, E., Hasik, M. and Blazewicz, M. (2011). FT-IR study of montmorillonite-chitosan nanocomposite materials. Spectrochimica Acta, 79: 784-788.

18. Vetrieval, S. and Pandurangan, A. (2004). Vapour-phase oxidation of ethylbenzene with air over mn-containing MCM-41 mesoporous molecular sieves. Applied Catalysis A: General, 264: 243-252.

19. Adam, F. and Iqbal, A. (2011). The oxidation of styrene by chromium-heterogenous catalyst prepared from rice-husk. Chemical Engineering Journal, 160(2): 742-750.

20. Ibrahem, S. and Ibrahem, H. (2013). Preparation and study properties of silica using sol-gel method. International Journal of Application or Innovation in Engineering \& Management, 12: 111-116.

21. Cruz, R. S. D., Silva, J. M. S. D., Arnold, U. and Schuchardt, U. (2001). Catalytic activity and stability of a chromium containing silicate in liquid phase cyclohexane oxidation. Journal of Molecular Catalysis A: Chemical, 171: 251-257.

22. Chassary P, Vincent, T. and Guibal, E. (2004). Metal anion sorption on chitosan and derivative materials: A strategy for polymer modification and optimum use. Reactive and Functional Polymers, 60:137-149. 
23. Kavitha, K, Sutha, S., Prabhu, M., Rajendran, V. and Jayakumar, T. (2013). In situ synthesized novel biocompatible titania-chitosan nanocomposites with high surface area and antibacterial activity. Carbohydrate Polymers, 93: 731-9.

24. Budnyak, T. M., Pylypchuk, I.V., Tertykh, V. A., Yanovska, E. S. and Kolodynska, D. (2015). Synthesis and adsorption properties of chitosan-silica nanocomposite prepared by sol-gel method. Nanoscale Research Letters, 10: 87: 1-10.

25. Budnyak, T., Tertykh, V. and Yanovska, E. (2014). Chitosan immobilized on silica surface for wastewater treatment. Materials Science (Medžiagotyra), 20: 177-182.

26. Qun, G. and Ajun, W. (2006). Effects of molecular weight, degree of acetylation and ionic strength on surface tension of chitosan in dilute solution. Carbohydrate Polymer, 64(1): 29-36.

27. Berge, T., Daugbjerg, N., Andersen, B. B. and Hansen, P. J. (2010). Effect of lowered pH on marine phytoplankton growth rates. Marine Ecology Progress Series, 416: 79-91.

28. Rejane C. G., Douglas de, B. and Odilio, B. G. A. (2009). A review of the antimicrobial activity of chitosan. Polímeros: Ciência e Tecnologia, 19(3): 241-247.

29. Jiexia, L., Yi, Z., Yujun T., Yuanming Z., Li, A., Li, T., Ming, S. and Chengwu, Z. (2013). Freshwater microalgae harvested via flocculation induced by pH decrease. Biotechnology for Biofuels, 6(98): 1-11. 